\title{
Distance Education and Academic Achievement in Business Administration: The case of the University of Akureyri
}

\author{
Ingi Runar Edvardsson and Gudmundur Kristjan Oskarsson \\ University of Akureyri, Iceland
}

\begin{abstract}
This paper first presents the development of distance education in Icelandic universities. Its second aim is to present a detailed analysis of the distance education practice at the University of Akureyri (UNAK), Iceland. Finally, the paper aims at analysing academic achievement, as well as attitudes towards courses, among campus and distance students in business administration at UNAK. The research is based on secondary data from the university's information system and official statistics. The findings reveal that distance education has increased significantly in Iceland in recent years. UNAK has had a leading role in developing distance education at university level in Iceland. Nearly half the students at UNAK are enrolled in distance education. Females take longer to finish their study than males, but they receive higher grades than males. Distance students take up to a year longer to finish their BSc programme than campus students. The study also has shown that distance students tend to receive lower grades in business administration at UNAK, and they are older, on average, than local students. Finally, both groups of students seem to express similar attitudes towards taught courses within the faculty. More research is needed in order to fully understand the factors behind the different achievements of distance and campus students.
\end{abstract}

Keywords: Distance education; Iceland; business administration; student achievement

\section{Introduction}

Education is highly valuable in a globalized knowledge society in which technological and social changes are rapid. In such a situation, education has an impact on people's employability and their inclusion in society.

Distance education has granted various groups of non-traditional students - such as people in rural communities, married couples with children, and people older than 25 years of age - access to educational institutions at university level. As a result, an ever-growing number of individuals are obtaining a university education through distance education.

Advanced information and communication technology (ICT) enables people to work and learn independent of time and space, so communities are no longer only based on geographical 
proximity (Peters, 2007). For education, this has revolutionised teaching and learning where new technology enables the transfer and transmission of text, pictures, and videos free of the constraints of time and space. This has rapidly increased the number of university students as non-traditional students have entered the universities in many countries.

Student achievement and retention, however, has been found to be lower among distance learners than among campus students. This has been explained by various factors such as age, social class, and social situation - i.e., lack of support, isolation, etc. (Fozdar \& Kumar, 2007). This fact still makes distance education an interesting research area, as the question of distance students' achievement and retention is far from settled.

The first aim of this paper is to provide insight into the development of distance education in Icelandic universities. Its second aim is to present a detailed analysis of the distance education practice at the University of Akureyri (UNAK), and, third, to analyse academic achievement and attitudes towards courses, among campus and distance students in business administration at UNAK.

The next section of the paper deals with theories of distance education, followed by a presentation of the methodology used. The fourth section provides information on distance education at UNAK, while the fifth presents the findings on student achievement and attitudes among students in business administration. The paper ends with a discussion and conclusions.

\section{Literature Review}

There are many different definitions of distance education. Bernard, Abrami, Borokhovski, Wage, Wozney et al. (2004, p. 388) synthesize recent definitions and define distance education as:

- Semi-permanent separation (place and/ or time) of learner and instructor during planned learning events.

- Presence of planning and preparation of learning materials, student support services, and final recognition of course completion by an educational organization.

- Provision of two-way media to facilitate dialogue and interaction between students and the instructor and among students.

Research has been undertaken in order to evaluate student attitudes, dropout/ retention and academic achievement in distance education compared to traditional classroom teaching. Among many factors identified as reasons for poorer achievement and higher dropout rates of distance education compared to classroom education are boredom with courses, financial difficulties, lack of feedback and encouragement, perception of isolation, insufficient motivation, dissatisfaction with requirements or regulations and change in career goals (Bernard et al., 2004; Fozdar \& Kumar, 2007; Woodley, 2004). Integration into the academic and social system may also be a case in point. According to the theory of Tinto, school dropouts tend to have lower commitment to the university social system due to nonconformity values or limited interaction with others in the college (Woodley, 2004). In Table 1, Woodley gives some examples of student and institutional characteristics that former studies have found that may influence students' progress. 
Edvardsson \& Oskarsson

Table 1. Examples of student and institutional characteristics that may influence student progress

\begin{tabular}{ll}
\hline Student characteristics & Institutional characteristics \\
\hline Academic ability & Type of institution \\
Academic preparedness & Teaching standards \\
Family background & Subject taught \\
Educational aspirations & Student accommodation \\
Study habits & Library facilities \\
Expectations about college & Laboratory facilities \\
Financial status & Student counselling \\
Work status & Assessment procedures \\
Place of residence & Teaching methods \\
Other characteristics & Tutorial support \\
\hline
\end{tabular}

Source: Woodley, 2004, pp. 51, 53.

According to Woodley (2004) much of the former research on distance education has focused on students' characteristics (Woodley, 2004). In Iceland, for instance, distance students tend to be older than campus students, are working part-time or full time, have taken some years off from study, are more often than not married with children, and live at some distance from universities (Oskarsson \& Edvardsson, 2007). Institutional research, however, is less common according to Woodley, but many issues related to institutional factors are relevant to explain student dropout or success. Among these are selective or open entry, qualifications of teaching staff, library facilities, and teaching methods and assessment.

Past research on the study outcomes of distance education compared to classroom teaching is not conclusive. Meyer $(2004 ; 2002)$ argues that there is no statistically significant difference between the two groups. Bernard et al. (2004, p. 397) conclude their extensive meta-analysis of 232 studies by noting “. . . that some applications of [distance education] are far better than classroom instruction and some are far worse.” Comparing distance and local learning, however, is no easy task, and several factors may distort the comparison, leading to unreliable results that are of only limited use (Meyer, 2004). One of the most significant factors that may reduce the value of the comparison, or even render it useless, is the fact that distance students and campus students are different types of groups. Do these groups for example share similar age composition, gender proportions, and preparation? The risk is that the comparison is of no value, because two different things are being compared - for example, apples and oranges (Howell, Law \& Lindsay, 2004).

\section{Research Methods}

To answer the question whether the results of distance and local students were comparable, information relating to grades, courses, students' gender, and age was retrieved, extending over the years 2001-2007, from the Stefania database, which serves as the university's information system. Information was obtained for a total of 410 courses taught during this period. To restrict the sample size, only those courses were selected that had been taught at least twice in classroom and in distance education at the same time. Another criterion for selecting courses was that the number of students in each course was not below 20, and no less than seven students registered either in classroom or distance education. A total of 204 different courses fulfilled those requirements. 
In order to improve the reliability of the survey, each taught course was examined individually. There are generally a larger number of registered students in each course than those who obtain a final grade, which should be taken into consideration when different groups of students are compared. There are many different reasons for students failing to complete courses however, and if this is not taken into account it may well distort the comparison (Howell et al., 2004). Should one, for example, include those who were registered for the course but did not in any way participate in the teaching? The authors, therefore, decided to limit the sample in each course to students who obtained a final grade. A $t$-test (Sanders \& Roberts, 2000) was applied to check the potential difference between the following factors: the grades of distance and local students, the grades of males and females, the age of distance and local students in each course, and the age of males and females in each course. A chi-square test was applied to check whether the gender distribution of local and distance students was identical.

\section{University of Akureyri}

The supply of distance education at Icelandic universities has grown rapidly, with new courses being added every year. One reason is the rising use of computers and the Internet in Iceland. In 2007, 91 percent of individuals used computers, and 91 percent used the Internet (Statistics Iceland, 2008a). At present, seven out of eight universities offer distance education of one type or another. In $2007,17,570$ students were registered at those universities, of which 2,776 (15.8\%) were registered in distance education (Statistics Iceland, 2008b). The distance studies are carried out in different ways, either by means of teleconferencing equipment or via the Internet. Each university has its own variation of course organisation and the implementation of the distance programme.

The University of Akureyri is located in the largest town in Iceland outside the capital area. The town, which is also a regional centre, is located in the North-Eastern part of the country, and has about 17, 000 inhabitants. UNAK was the third university founded in Iceland. At that time in 1987, the other two were in Reykjavik, the centre of higher education in Iceland. Before UNAK was founded, all students from rural areas had to move to Reykjavik in order to receive higher education. Today, Reykjavik still occupies a dominating position within the university system, since 75.9 percent to 86 percent of students live or study in the capital area (Statistics Iceland, 2008b; 2008c) while 63 percent of the population live in the larger Reykjavík area. From the beginning, UNAK has been of great importance to Akureyri and the scattered provincial settlements of Iceland. Currently, the university has four faculties: the Faculty of Law and Social Sciences, the Faculty of Health Sciences, the Faculty of Education, and the Faculty of Business and Science. The state-funded university operates using an open access model, except in the Faculty of Health Science where numerous exclusionary clauses are used to select students after the first term.

The University's student population has grown rapidly in recent years, as can be seen from Table 2. In 1998, the total number of students was 482, but it rose to 1,338 students in 2007 or 7.6 percent of all university students in Iceland. By far the largest increase was among distance students. The number of local students nearly doubled in the period, while that of distance students increased fifteen-fold. In autumn 2007, distance students were 48.1 percent out of 1338 students, and 22.8 percent of all distance students in Iceland. UNAK provided distance education to about 20 towns and cities throughout Iceland, transforming UNAK from a regional to a national university. 
Edvardsson \& Oskarsson

Table 2. Number of students at the University of Akureyri 1998-2006

\begin{tabular}{|c|c|c|c|c|c|c|c|c|c|c|}
\hline & 1998 & 1999 & 2000 & 2001 & 2002 & 2003 & 2004 & 2005 & 2006 & 2007 \\
\hline \multicolumn{11}{|l|}{ Local students } \\
\hline Male & 104 & 106 & 126 & 146 & 182 & 229 & 225 & 213 & 217 & 192 \\
\hline \multirow[t]{2}{*}{ Female } & 335 & 358 & 366 & 405 & 452 & 603 & 547 & 567 & 546 & 502 \\
\hline & 439 & 464 & 492 & 551 & 634 & 832 & 772 & 780 & 763 & 694 \\
\hline \multicolumn{11}{|l|}{ Distance students } \\
\hline Male & 12 & 21 & 27 & 98 & 97 & 120 & 138 & 131 & 121 & 136 \\
\hline Female & 31 & 73 & 158 & 274 & 337 & 478 & 606 & 610 & 554 & 508 \\
\hline & 43 & 94 & 185 & 372 & 434 & 598 & 744 & 741 & 675 & 644 \\
\hline \multicolumn{11}{|l|}{ Total } \\
\hline Male & 116 & 127 & 153 & 244 & 279 & 349 & 363 & 344 & 338 & 328 \\
\hline Female & 366 & 431 & 524 & 679 & 789 & 1081 & 1153 & 1177 & 1100 & 1010 \\
\hline & 482 & 558 & 677 & 923 & 1068 & 1430 & 1516 & 1521 & 1438 & 1338 \\
\hline
\end{tabular}

Table 2 also reveals that females comprise 75.5 percent of the total number of students, which can be explained by the fact that large faculties of UNAK are those of health sciences and education i.e. providing education for traditional women's jobs, such as nursing and teaching.

Figure 1. The average age of students at UNAK 1998-200

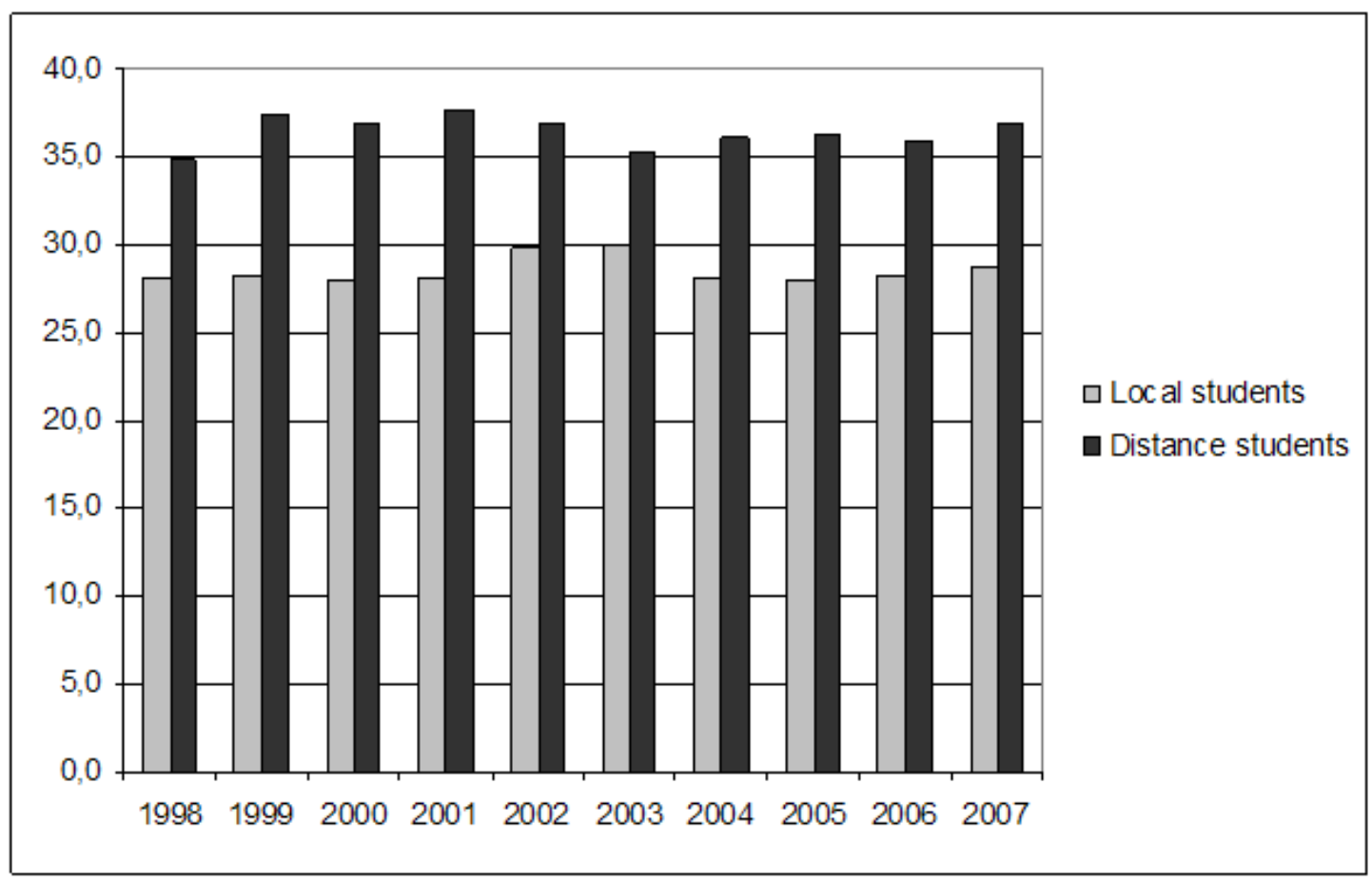


The majority of students at the university are relatively mature. In 2007, the average age of students was 32.6 years. When distance and local students are compared, it is found that distance students tend to be substantially older than local students (see Figure 1).

\section{Distance Education in Business Administration}

The Faculty of Business and Science first offered distance studies in 2000. The program was initially developed as an on-campus program, and later adapted to distance education. This faculty has now the largest number of students within UNAK, as well as the largest share of distance students. Table 3 shows the number of students completing courses at the faculty over the past seven years.

Table 3. Number of students completing Faculty of Business and Science courses 2001-2007

\begin{tabular}{|c|c|c|c|c|c|c|c|}
\hline & 2001 & 2002 & 2003 & 2004 & 2005 & 2006 & 2007 \\
\hline \multicolumn{8}{|l|}{ Local students } \\
\hline Male & 111 & 139 & 115 & 96 & 103 & 107 & 132 \\
\hline \multirow[t]{2}{*}{ Female } & 101 & 121 & 112 & 115 & 116 & 120 & 138 \\
\hline & 212 & 260 & 227 & 211 & 219 & 227 & 270 \\
\hline \multicolumn{8}{|l|}{ Distance students } \\
\hline Male & 53 & 62 & 100 & 100 & 78 & 71 & 77 \\
\hline \multirow[t]{2}{*}{ Female } & 74 & 94 & 152 & 172 & 187 & 195 & 190 \\
\hline & 127 & 156 & 252 & 272 & 265 & 266 & 267 \\
\hline \multicolumn{8}{|l|}{ Total } \\
\hline Male & 164 & 201 & 215 & 196 & 181 & 178 & 209 \\
\hline \multirow[t]{2}{*}{ Female } & 175 & 215 & 264 & 287 & 303 & 315 & 328 \\
\hline & 339 & 416 & 479 & 483 & 484 & 493 & 537 \\
\hline
\end{tabular}

Source: Stefania UNAK's information system

The Faculty of Business offers most of its courses concurrently to several locations in Iceland in subjects relating to business studies and natural resource science. Computer science, however, is not offered in distance mode. In the following, the focus will be on business administration.

A vast variety of teaching methods are used within the faculty. All teaching is organised around WebCT, where students can: (a) gain information on lecture schemes; (b) email the instructor and fellow students in their cohort; (c) participate in discussions by means of a discussion board; and (d) take quizzes, download overheads, access reading lists, and so on. Moreover, students can gain information on their assessment results in the grade book. Distance and classroom teaching, however, are separated. Classroom teaching is run from 8:00 a.m. until 12:00 noon most days, while distance education is undertaken in the evenings from 5:00 p.m. to 9:00 p.m., and during Saturdays (organised so that students can work along with their studies). Textbooks, reading materials, examinations, and assignments are the same for all students, independent of teaching methods, however.

Distance education in the business administration is organised as a group activity (i.e., it is set-up in cooperation with many learning centres throughout Iceland, where the students come to take part in lectures and discussions via interactive teleconference equipment supervised by a lecturer). In general, distance students have five meeting points, two hours at a time, for each 
academic course in the study. New distance students to the faculty attend campus for a few days in the beginning of the first semester. Also, they visit UNAK every mid-term after that for a few days for lectures, course work, discussion, etc. The teaching model in business administration bears significant similarity to the fourth generation of distance education, The Flexible Learning Model, as shown in Table 4.

Table 4. Generations of Distance Education

\begin{tabular}{|c|c|c|}
\hline Generation & Model & Delivery technologies \\
\hline First generation & The Correspondence Model & Print \\
\hline Second generation & The Multi-media Model & $\begin{array}{l}\text { Print, audio tapes, video } \\
\text { tapes, computer based } \\
\text { learning (e.g., CML/CAL } \\
\text { /IMA), interactive video } \\
\text { (disk and tape) }\end{array}$ \\
\hline Third generation & The Teleleaming Model & $\begin{array}{l}\text { Audio teleconferencing, } \\
\text { videoconferencing, audio- } \\
\text { graphic-communication, } \\
\text { Broadcast TV/Radio }\end{array}$ \\
\hline Fourth generation & The Flexible Learning Model & $\begin{array}{l}\text { Interactive multimedia } \\
\text { (IMM) online, internet } \\
\text { based access to www } \\
\text { resources, computer mediated } \\
\text { communications }\end{array}$ \\
\hline Fifth generation & The Intelligent Flexible & $\begin{array}{l}\text { Interactive multimedia } \\
\text { Learning Model (IMM) online, internet } \\
\text { based access to www } \\
\text { resources, computer mediated } \\
\text { communications, using automated } \\
\text { response systems, campus portal } \\
\text { assess to institutional process and } \\
\text { resources. }\end{array}$ \\
\hline
\end{tabular}

Source: Fozdar and Kumar, 2007, p. 3.

\section{Student Progression}

It is interesting to analyze the progression of the two groups of students within the faculty from start to finish. Table 5 shows the average number of semesters it took students to complete a bachelor degree in the years 2001-2007. Table 5 reveals that, in general, campus male students complete their studies in six semesters (i.e., three years). Females take about 0.5 semesters longer to finish their degree than males. Also, it is common that distance students graduate one year later than campus students (7.7-8 semesters). Table 5 shows that the difference in progression between campus and distance students is significant both between males and females and in general. 
Edvardsson \& Oskarsson

Table 5. The number of semesters students $(N=161)$ require to complete bachelor degree in business administration

\begin{tabular}{|c|c|c|c|c|}
\hline & Male & Female & All & $\mathrm{p}$-value $\mathrm{b}^{\mathrm{a}}$ between gender \\
\hline Local students & 6.1 & 6.6 & 6.4 & 0.018 \\
\hline Distance students & 7.7 & 8.0 & 7.9 & 0.231 \\
\hline All & 7.1 & 7.5 & 7.4 & 0.063 \\
\hline $\begin{array}{l}\text { p-value } \mathrm{e}^{\mathrm{b}} \text { between local } \\
\text { andstance students }\end{array}$ & $<0.001$ & $<0.001$ & $<0.001$ & \\
\hline
\end{tabular}

astudents t-test

\section{Comparing Teaching Methods}

To compare the results of the two groups within the Faculty of Business and Science, 204 courses were examined, with student numbers ranging from 20 to 192, with an average of 61.1 students enrolled in each course. On average, each of those courses was completed by 27.9 local students and 33.1 distance students. When looking at the grades, it was found that local students had a higher average grade in 137 courses, compared to 67 courses where the distance students had a higher average grade. Using a 5 percent significance limit, 42 courses showed a significant difference between the grades of distance and local students - in eight of these the difference was in favour of the distance students. On the basis of a 1 percent significance limit, 20 courses showed a significant difference, always in favour of the local students (see Table 6).

Table 6. Proportion of courses showing a significant difference between student groups

\begin{tabular}{lr}
\hline Proportion of courses where local students have higher grades & $16.7 \%$ \\
Proportion of courses where distance students have higher grades & $3.9 \%$ \\
Proportion of courses where woman have higher grades & $7,8 \%$ \\
Proportion of courses where men have higher grades & $3,4 \%$ \\
Proportion of courses where distance students are of higher age & $91,7 \%$ \\
Proportion of courses where woman are of higher age & $13,7 \%$ \\
Proportion of courses where men are of higher age & $0,5 \%$ \\
\hline (5\% significance limit). &
\end{tabular}

In the courses investigated, the proportion of females ranged from 20 percent to 90 percent, with an average of 60.1 percent. Generally, the proportion of females was higher among distance students than local students. In 164 courses, the proportion of females among distance students was higher, and in 44 of those courses the difference was significant based on a 5 percent significance limit. The Faculty of Business and Science is the only faculty where it is possible to make an annual gender comparison. Females had a higher average grade in 119 courses, with a significant difference in 16 of those based on a 5 percent significance limit. Males, on the other hand had a higher average grade in 85 courses, although the difference was only significant in seven courses, based on a significance limit of 5 percent.

When considering the age composition of the students, the average age of local students is 27.5 years, compared to 36.2 years in the case of distance students. In 203 out of 204 courses, the average age of distance students was higher than that of local students; in 187 cases the difference 
was significant, based on a 5 percent significance limit. Where the difference was significant, the distance students were on average 9.1 years older than the local students. The female's mean age was 32.5 years, compared to 31.2 years for males. The difference was significant 29 times, based on a 5 percent significance limit. Females were older in 28 cases, compared to males in one case.

When comparing the two groups, the distance students tend to receive lower grades than local students, they tend to be older (by 9.1 year), and include a higher number of females.

\section{Students’ Attitudes}

Former studies have noted that boredom with courses, as well as dissatisfaction with requirements, could explain poorer performance of distance students as compared to local students (Fozdar \& Kumar, 2007; Bernard et al., 2004; Woodley, 2004). In order to analyze students' attitudes towards courses within the faculty, the assessment of courses given by students at the end of each semester was examined. Data for four semesters were retrieved from spring 2006 to autumn 2007. In was possible to compare the overall grade between local and distance students in 57 courses. In 36 instances, local students gave the course a higher score, while in 21 instances distance students gave the course a higher score. The difference was significant in 11 courses. Where the difference was significant, it is interesting to see that in six courses distance students gave the course a higher score, as can be seen in Table 7 .

Table 7. Comparison of local and distance students' attitudes towards courses

\begin{tabular}{lcccc}
\hline & $\begin{array}{c}2006 \\
\text { Spring }\end{array}$ & $\begin{array}{c}2006 \\
\text { Autumn }\end{array}$ & $\begin{array}{c}2007 \\
\text { Spring }\end{array}$ & $\begin{array}{c}2007 \\
\text { Autumn }\end{array}$ \\
\hline Number of courses to compare & 11 & 17 & 13 & 16 \\
Number of local courses with higher satisfaction & 8 & 11 & 7 & 10 \\
Number of distance courses with higher satisfaction & 3 & 6 & 6 & 6 \\
& & & & 2 \\
Number of courses with significant difference (0.05) & 2 & 5 & 2 & 0 \\
Number local courses with significantly higher satisfaction & 1 & 3 & 1 & 2 \\
Number distance courses with significantly higher satisfaction & 1 & 2 & 1 & \\
\hline
\end{tabular}

Source: Stefania UNAK's information system

Interestingly, this shows that distance students and local students seem to be equally satisfied with courses within the faculty. They express similar attitudes towards taught courses within the faculty.

\section{Discussion}

This paper presented research based on secondary data from a university's information system. The aim is to analyse academic achievement and attitudes of campus and distance students in the Faculty of Business Administration and Science at the University of Akureyri, Iceland. The findings reveal that it takes females longer to finish their studies than males, and that it takes distance students up to a year longer to finish their BSc programme than do campus students. The study also shows that distance students, on average, tend to receive lower grades and are older than local students. 
Finally, both groups of students seem to be expressing similar attitudes towards taught courses within the faculty.

In the literature review, it was suggested that lower commitment, institutional factors, and students' characteristics are relevant in explaining student dropout and success. Two institutional characteristics stand out at UNAK in order to explain the success of distance and campus students. The first is the teaching methods; that is traditional campus teaching versus modified campus and online learning. As distance teaching is done, by in large, through teleconferencing and through some pre-recorded lectures, distance students have fewer contact hours with teachers than campus students.

The second factor is related to less tutorial support for distance students, as they have more difficulties to meet teachers, consultants, and support staff. This means that distance students experience more limited interaction with the social system at UNAK, and therefore lower commitment that could arguably lead to more dropouts. The cooperation with learning centres throughout Iceland is intended to increase interaction and group activity among distance learners.

The fact that females take longer to finish their studies is explained partly, at least in Iceland, by the fact that many females in university education give birth during their studies and assume primary responsibility for raising the children. More often than not, female students leave the university for a short period or undertake part-time studies. The age difference between distance students and campus students was assumed to be younger, because single people can move more easily between locations for the purpose of education, whereas older students are less mobile due to family or employment situations. As the distance programmes at UNAK are, in most cases, highly flexible, and many of the distance students are employed while studying, it generally takes them longer to complete their academic programmes.

High workload and family obligations, combined with university studies, is common practice among distance students in Iceland, and may explain their lower grades in part. Further analysis, however, is needed to evaluate the impact of distance education versus classroom instruction on the actual achievement of students.

The findings of this study with regard to poorer performance and longer study periods among distance students are in accordance with past research (Fozdar \& Kumar, 2007; Woodley, 2004). Although gender and age have been mentioned briefly in the literature, those aspects have not been given the attention they deserve as explanatory variables, as our results indicate. Our findings -that there is no significant difference in attitudes towards taught courses among campus versus distance students - seem to contradict earlier research.

This research was carried out in only one faculty within one university in one country, and is based on a registration data (secondary data). Its results, therefore, should be interpreted with care. Future research is needed, as the subject under investigation is quite complicated. Future research should involve case studies and interviews, as well as surveys where students' backgrounds are analysed, as well as the character of the educational institutions with regard to potential impact on students' overall academic performance.

\section{Conclusions}

The use of distance education has increased rapidly in recent years. Past research has indicated, however, that the achievement of distance students, in many cases, has been less satisfactory than 
that of campus students. This holds consequence for both students and the community. Distance students may waste time, money, and energy in unfinished studies, or may realise poorer career possibilities due to lower grades. For the community, this could mean increased cost of education, as well as decreased potential skills and qualifications.

In order to address this problem, this paper first provides some insight into the development of distance education in Icelandic universities, and second, presented a detailed analysis of the distance education practice at the University of Akureyri. Finally, the main thrust of the paper has been devoted to the analysis of academic achievement, as well as attitudes towards courses, among campus and distance students in business administration at UNAK.

The findings reveal that it takes females longer to finish their studies than males, and that it takes distance students up to a year longer to finish their BSc programme than campus students. The study also has shown that distance students tend to receive lower grades, and, on average, that they are older than local students. Both groups of students seem to manifest equal levels of satisfaction with taught courses within the faculty.

In the paper, it is shown that distance education has greatly increased in Iceland in recent years. UNAK has had a leading role in the development of distance education at university level in Iceland. Nearly half of the number of students at UNAK is enrolled in distance education.

\section{Notes}

No formal statistics is available at UNAK on succession rates of students. Such calculations are often complicated. In our case we followed the progression of those students that registered for the final year project, in all 161 students' progresses were analysed, but we were unable to follow the students that carried out part of their studies at other universities.

The assessment consists of an online questionnaire on the organization of courses, teaching facilities and materials, the performance of teachers, assignments, interaction between students and teachers, and so on.

\section{References}

Bernard, R. M., Abrami, P. C., Borokhovski, E., Wage, A., Wozney, L., Wallet, P. A., Fiset, M., \& Huang B. (2004). How does distance education compare with classroom instruction? A meta-analysis of the empirical literature. Review of Educational Research, 74(3), 379-439.

Fozar, B. I., \& Kumar, L. S. (2007). Mobile learning and student retention. International Review of Research in Open and Distance Learning, 8(2), 1-16. http://www.irrodl.org/index.php/irrodl/article/view/345/927

Howell, S. L., Laws, R. D., \& Lindsay, N. K. (2004). Revaluating course completion in distance education. Avoiding the comparison between apples and oranges. The Quarterly Review of Distance Education, 5(4), 243-252.

Meyer, K. A. (2002). Quality in distance education: Focus on on-line learning. ASHE-ERIC Higher Education Report Series. http://www.eric.ed.gov/ERICWebPortal/custom/portlets/recordDetails/detailmini.jsp? nfpb 
=true\&_\&ERICExtSearch_SearchValue_0=ED470542\&ERICExtSearch_SearchType_0=n o\&accno=ED470542

Meyer, K. A. (2004). Putting the distance learning comparison study in perspective: Its role as personal journey research. Online Journal of Distance Learning Administration, 7(1). http://www.westga.edu/ distance/ojdla/spring71/meyer71.html

Oskarsson, G. K., \& Edvardsson, I. R. (2007). Distance education as a source of upgrading in rural areas: The case of the University of Akureyri. In H. Oskarsson (Ed.), Afmcelisrit Háskólans á Akureyri 2007 [In Danish]. Akureyri: University of Akureyri.

Peters, K. (2007). m-Learning: Positioning educators for a mobile, connected future. International Review of Research in Open and Distance Learning, 8(2). http://www.irrodl.org/index.php/irrodl/article/view/350/914

Sanders, D. H., \& Robert, K. S. (2000). Statistics: A first course. (6th ed.). USA: McGraw-Hill Higher Education.

Statistics Iceland (2008a). Tölvu og internetnotkun einstaklinga 2002-2007. [In Danish] http://www.hagstofa.is/?PageID=693

Statistics Iceland (2008b). Skráðir nemendur í skólum á háskólastigi eftir kyni og kennsluformi 2001-2007. [In Danish] http://www.hagstofa.is/?PageID=783

Statistics Iceland (2008c). Mannfjöldi eftir sveitarfélagi, kyni og aldri 1. desember 1997-2007. [In Danish] http://www.hagstofa.is/?PageID=624

Woodley, A. (2004). Conceptualizing student dropout in part-time distance education: pathologizing the normal. Open Learning, 19(1), 47-63. 